\title{
Filter-type and sample handling affect determination of organic substrate uptake by bacterioplankton
}

\author{
Ronald P. Kiene*, Laura J. Linn \\ Department of Marine Sciences, University of South Alabama, Mobile, Alabama 36688, USA \\ and \\ Dauphin Island Sea Lab, Dauphin Island, Alabama 36528, USA
}

\begin{abstract}
Natural assemblages of bacterioplankton (coastal seawater and seawater filtrates), treated with radiolabeled organic substrates, were used to test the effectiveness of various types of $0.2 \mu \mathrm{m}$ pore size filters in capturing labeled cell materials. The highest retention of cell material was observed with filters made of either polyethersulfone (PES), mixed cellulose esters (MCE) or Nylon. PES filters retained up to $22 \%$ less than MCE or Nylon filters in some comparisons, but in most cases these filters gave similar, apparently high retention of cell materials. In contrast, retention of labeled cell material by track-etched polycarbonate (PC) or polyester (PE) filters was 10 to $80 \%$ less than for PES, MCE or Nylon filters, even at low filtration vacuum $(5 \mathrm{~cm} \mathrm{Hg})$. Radiolabel lost from PC filters was recovered as dissolved compounds in the filtrates, and tests showed that cell breakage/leakage occurred, not during filtration per se, but rather at the end of filtration when filters ran dry. Higher filtration vacuum over the range 5 to $38 \mathrm{~cm} \mathrm{Hg}$ caused greater losses with PC filters whereas retention of radiolabel by PES filters was nearly independent of vacuum. Losses on PC filters were greatest during early phases of incubations, when label in the cells was found mostly as untransformed parent substrate, and losses were greater for substrates known to function as intracellular osmolytes (e.g. glycine betaine and dimethylsulfoniopropionate) than for substrates (e.g. leucine and glucose) that were rapidly incorporated into macromolecules. Treatment of PESfiltered cells by a cold osmotic shock procedure resulted in nearly identical losses to those which occurred with nonshocked cells on PC filters. Likewise, addition of formalin ( $2 \%$ final concentration) to a seawater filtrate culture which had already taken up ${ }^{14} \mathrm{C}$-glycine betaine caused rapid losses of ${ }^{14} \mathrm{C}$ from particulate materials, resulting in the same amount of loss as occurred when parallel live samples were filtered onto PC filters. The results suggest that a major fraction of the soluble components of bacterioplankton can be selectively lost during filtration through polycarbonate-type membranes, and by procedures which subject cells to osmotic shock and poisoning. Furthermore, our results indicate that PES, MCE and nylon filters function similarly well at retaining most cell materials.
\end{abstract}

KEY WORDS: Filtration - Artifact · Osmolyte - DOC - Filter comparison - Betaine

•E-mail: rkiene@jaguar1.usouthal.edu
Filtration is used widely in many aspects of microbial ecology research, therefore the performance of various filtration techniques needs to be thoroughly understood. One common application is the use of membrane filters to capture whole cells during uptake studies employing addition of radiolabeled substrates to aquatic samples (Wright \& Hobbie 1966, Griffiths et al. 1974, Azam \& Hodson 1981, Hodson et al. 1981, Coffin 1989, Griffith et al. 1990, Middelboe et al. 1995, Rich et al. 1996). Termination of incubations with radiolabeled substrates is often best achieved by filtering cells, rather than addition of poisons, because poisons such as formalin, $\mathrm{HgCl}_{2}$ and strong acids can cause losses of label from the cells (Griffiths et al. 1974, Palumbo et al. 1983). Filtration itself can be problematic, however, if conditions are harsh (high vacuum shear, or desication on dry filters), as this can cause release of dissolved organic compounds, especially from eucaryotes like microzooplankton and phytoplankton (Fuhrman \& Bell 1985, Goldman \& Dennet 1985, Nagata \& Kirchman 1990). While most $0.2 \mu \mathrm{m}$ membrane filters do effectively remove the majority of bacterial cells from water, as evidenced by insignificant numbers of acridine orange- or DAPI-positive cells in the filtrates (Hobbie et al. 1977), few aquatic microbial ecology studies have addressed the efficiency of membrane filters for retention of all bacterial cell materials. Furthermore, a wide variety of membrane filters have been used by investigators carrying out microbial uptake studies, yet little information exists about the relative effectiveness of the different filters used.

We recently investigated uptake of the low molecular weight osmotic solutes, glycine betaine (GBT), and dimethylsulfoniopropionate (DMSP) by natural microbial communities (Kiene \& Hoffmann Williams 1998, Kiene et al. 1998). We used radiolabeled substrates to measure uptake into filterable material (cells) and in preliminary tests we noted that $0.2 \mu \mathrm{m}$ Supor filters 
(polyethersulfone; PES) generally retained higher amounts of radioactivity when compared with other $0.2 \mu \mathrm{m}$ membrane filters, including Nuclepore (polycarbonate $\mathrm{PC}$ ) and Anopore (aluminum oxide) types when a water sample was passed simultaneously through each filter type under identical vacuum conditions. This finding led us to investigate the performance of a wider variety of popular filter-types in uptake assays. In addition, we tested how factors such as type of radiolabeled substrate, time of incubation, and sample handling (filtration vacuum, osmotic shock and addition of poison [formalin]) affected retention of radiolabeled cell materials by selected filters.

Materials and methods. Filter types used: The filters used in this study were all rated at $0.2 \mu \mathrm{m}$ pore size by the respective manufacturers. The types of filter materials tested included polyethersulfone (PES; Gelman, Supor-200); mixed cellulose esters (MCE, Poretics), track-etched polycarbonate (PC; Nuclepore or Poretics); track-etched polyester (PE; Poretics); Nylon (Poretics, Magna Nylon) and aluminum oxide (AO, Whatman, Anopore). Twenty-five $\mathrm{mm}$ diameter sized filters were used in all cases. General characteristics of the filter materials used are given in Table 1. Detailed information about the characteristics of the filter materials are widely available in catalogs of the respective manufacturers. Most of the comparisons in this study were between $0.2 \mu \mathrm{m}$ Supor-PES and Nuclepore-PC filters, and most experiments utilized ${ }^{14} \mathrm{C}$-GBT (see below) as the representative uptake substrate. We arbitrarily chose Supor-PES filters as a reference with which to compare other filters because we routinely used these filters and we had previously determined that they gave low abiotic adsorption blanks, and were amenable to extraction in organic solvents.

Water collection and culture generation: Coastal seawater samples used for microbial uptake experiments and filter comparisons were collected in the vicinity of Dauphin Island, Alabama, located in the Northern Gulf of Mexico ( $30^{\circ} 15^{\prime} \mathrm{N}, 88^{\circ} 05^{\prime} \mathrm{W}$ ). Water was collected from the shore (pier or beach) into a polycarbonate carboy. In some experiments, freshly collected whole water was used, while in other experiments, filtrate cultures were used so that the microbial community consisted mainly of bacteria. The cultures were generated by filtering water through Whatman GF/F glass fiber filters ( $>0.7 \mu \mathrm{m}$ nominal retention) using gravity only. Prior to the initiation of uptake experiments, the filtrate cultures were incubated in the dark for 24 to $48 \mathrm{~h}$, during which time endogenous substrates became depleted and bacterial abundances typically doubled from $1-2$ to $2-4 \times 10^{6}$ cells $\mathrm{ml}^{-1}$. Microscopic examination showed that filtrate cultures contained mainly free living bacteria, with few microzooplankton or photoautotrophs observed at the time experiments were carried out.

Table 1. Filter-types used and their general characteristics

\begin{tabular}{|c|c|c|c|c|}
\hline $\begin{array}{l}\text { Filter membrane } \\
\text { material and abbreviation }\end{array}$ & $\begin{array}{c}\text { Pore-size } \\
(\mu \mathrm{m})\end{array}$ & $\begin{array}{l}\text { Filter manufacturer } \\
\text { and trade name }\end{array}$ & Characteristics ${ }^{b}$ & Comments \\
\hline $\begin{array}{l}\text { Polyethersulfone } \\
\text { (PES) }\end{array}$ & 0.2 & $\begin{array}{l}\text { Gelman Supor-200 } \\
\text { Poretics, Osmonics }\end{array}$ & $\begin{array}{l}\text { Sponge-like matrix filter. } \\
\text { Irregular surface. Rapid } \\
\text { filtration }\end{array}$ & $\begin{array}{l}\text { Mechanically strong, } \\
\text { and stable in methanol: } \\
\text { chloroform }(12: 5)\end{array}$ \\
\hline $\begin{array}{l}\text { Polycarbonate, } \\
\text { tracked-etched (PC) }\end{array}$ & 0.2 & $\begin{array}{l}\text { Nuclepore, Costar } \\
\text { Poretics, Osmonics }\end{array}$ & $\begin{array}{l}\text { Well defined pore size. } \\
\text { Slow filtration rate. } \\
\text { Very flat surface }\end{array}$ & Little moisture retention \\
\hline $\begin{array}{l}\text { Polyester, track- } \\
\text { etched (PE) }\end{array}$ & & Poretics, Osmonics & $\begin{array}{l}\text { Well defined pore size. } \\
\text { Slow filtration rate. } \\
\text { Very flat surface }\end{array}$ & $\begin{array}{l}\text { Similar in most respects } \\
\text { to track etched poly- } \\
\text { carbonate }\end{array}$ \\
\hline $\begin{array}{l}\text { Mixed esters of } \\
\text { cellulose }(\mathrm{M} A \mathrm{CE})\end{array}$ & 0.2 & Poretics, Osmonics & $\begin{array}{l}\text { Sponge-like matrix filter. } \\
\text { Irregular surface. Rapid } \\
\text { filtration }\end{array}$ & $\begin{array}{l}\text { Mechanically weak, } \\
\text { tears easily }\end{array}$ \\
\hline Nylon & & $\begin{array}{l}\text { Poretics, Osmonics - } \\
\text { Magna Nylon }\end{array}$ & $\begin{array}{l}\text { Sponge-like matrix filter. } \\
\text { Irregular surface. Rapid } \\
\text { filtration }\end{array}$ & $\begin{array}{l}\text { Mechanically strong, } \\
\text { and stable in methanol: } \\
\text { chloroform }(12.5)\end{array}$ \\
\hline $\begin{array}{l}\text { Aluminum oxide } \\
(\mathrm{AO})\end{array}$ & 0.2 & Anopore, Whatman & $\begin{array}{l}\text { Flat surface. Moderate } \\
\text { filtration rate }\end{array}$ & Brittle \\
\hline
\end{tabular}


Comparisons of filter-type, substrate-type and incubation time in live bacteria uptake assays: GF/F filtrate cultures were treated with either methyl ${ }^{14} \mathrm{C}-\mathrm{GBT},{ }^{35} \mathrm{~S}$ DMSP, U- ${ }^{14} \mathrm{C}$-glucose, or U- ${ }^{14} \mathrm{C}$-leucine, with concentrations ranging from 5 to $16 \mathrm{nM}$ (600 to $12700 \mathrm{dpm}$ $\mathrm{ml}^{-1}$ ), depending on the substrate and experiment. GBT and DMSP are examples of naturally-occurring, low molecular weight osmotic solutes, and both of these compounds appear to be taken up by the same transport system in marine microorganisms (Kiene et al. 1998). Leucine is an amino acid which is rapidly assimilated into proteins and is widely used in uptake assays by microbial ecologists (Kirchman et al. 1985, Simon \& Azam 1989). Glucose was used because it is a major substrate for bacterioplankton in the sea (Rich et al. 1996), and available evidence suggests that marine bacteria take it up by a transport mechanism which differs from that used for most amino acids and osmolytes (DeLong \& Yayanos 1987, Logan \& Kirchman 1991).

After substrate addition to the filtrate cultures, $5 \mathrm{ml}$ sub-samples were withdrawn by pipette at selected times (typically $10 \mathrm{~min}, 2 \mathrm{~h}$ and $24 \mathrm{~h}$ ) and transferred to a 10-place Hoefer filtration manifold set up with several different filter types (in duplicate or triplicate). The samples were filtered using a vacuum which was typically 5 to $10 \mathrm{~cm} \mathrm{Hg}$. Vacuum was carefully monitored during all experiments and the effects of different vacuum levels were evaluated in 1 experiment (see below). After filters ran dry they were quickly rinsed with $3 \times 1 \mathrm{ml}$ of $0.2 \mu \mathrm{m}$ filtered seawater (FSW) of the same salinity as the sample. After the final rinse, and with the vacuum still on, the filters were removed and placed into scintillation vials with $5 \mathrm{ml}$ of Ecolume (ICN Biomedicals) for determination of radioactivity by liquid scintillation counting (Packard Tri-Carb model $2500 \mathrm{TR}$ ). In 1 experiment, 5 different filter types (PES, MCE, PC, PE and Nylon) were compared. In addition, a second set of Supor-PES filters was included and after rinsing with FSW, they were treated with $5 \mathrm{ml}$ of ice-cold $5 \%$ trichloroacetic acid (TCA). The TCA was allowed to stand on the filters for $5 \mathrm{~min}$ prior to being drawn through the filters. Radioactivity remaining on filters after cold TCA treatment is generally considered to be material assimilated into cellular macromolecules (Kirchman et al. 1985).

Time course of ${ }^{14} \mathrm{C}$-GBT and ${ }^{35} \mathrm{~S}$-DMSP uptake, retention, and assimilation: Information on the rates at which osmotic solute substrates were accumulated intracellularly and ultimately assimilated were obtained by following the amount of total uptake and the amount of untransformed substrate captured on the filters over time. Replicate samples $(250 \mathrm{ml}$ ) from the same filtrate culture were treated with either ${ }^{14} \mathrm{C}$-GBT

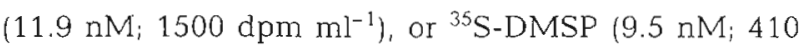
$\mathrm{dpm} \mathrm{ml}^{-1}$ ). These samples were incubated in the dark in Tetlon bottles at $27^{\circ} \mathrm{C}$. At selected time points, replicate $10 \mathrm{ml}$ sub-samples were taken by pipette for total uptake into particulates. Sub-samples were filtered onto Supor-PES filters, which were assayed for radioactivity in Ecolume. At the same time points, parallel PES filters $(10 \mathrm{ml}$ filtered) were taken for analysis of untransiormod substrate by placing filters into $5 \mathrm{ml}$ of an extraction fluid consisting of methanol, chloroform and water (MCW, 12:5:1). The extraction fluid contained 50 to $100 \mathrm{nmol}$ of unlabeled GBT or DMSP to aid recovery of the respective isotopes. After $>24 \mathrm{~h}$, the extracted filters were removed from the vials and rinsed with methanol into the same extraction vial. The rinsed filters were placed in a clean scintillation vial, allowed to dry in a fume hood, then counted in Ecolume. The activity retained on these extracted filters represented non-extractable material, presumably macromolecules. The MCW extract was dried under $\mathrm{N}_{2}$, reconstituted in pure water and injected into an HPLC. The peaks representing GBT or DMSP were collected and the radioactivity determined by liquid scintillation methods. Further details on these procedures are given elsewhere (Kiene \& Hoffmann Williams 1998). Recovery of radioactivity as the untransformed parent compound (HPLC peak) plus the non-extractable material remaining on the PES filter averaged $80 \%\left({ }^{35} \mathrm{~S}\right.$-DMSP) and $90 \%\left({ }^{14} \mathrm{C}\right.$-GBT $)$ of the activity found on parallel non-extracted filters, indicating that these fractions comprised the majority of labeled material on the filters

Effects of filtration vacuum: The effects of filtration vacuum on retention. of ${ }^{14} \mathrm{C}$ by either Supor-PES or Nuclepore-PC filters was investigated using a 48 h old filtrate culture treated with $10 \mathrm{nM}{ }^{14} \mathrm{C}$-GBT. Samples were taken approximately $3 \mathrm{~h}$ after addition of labeled GBT. Triplicate filters of each type were used at each vacuum level. Four vacuum levels $(5,13,19$ and $39 \mathrm{~cm}$ $\mathrm{Hg}$ ) were tested within a 30 min period, with sampling proceeding from low to high vacuum.

Filter and filtrate label recovery: Ten ml samples of a ${ }^{14} \mathrm{C}$-GBT-amended filtrate culture were filtered as described above onto $0.2 \mu \mathrm{m}$ Supor-PES and Nuclepore-PC filters using the Hoefer filtration manifold. Triplicate samples for each filter type were taken and each was rinsed with exactly $2 \times 0.5 \mathrm{ml}$ of FSW. The filtrates $(11 \mathrm{ml}$ total) were captured in scintillation vials. Three $1 \mathrm{ml}$ subsamples from each filtrate were taken for determination of total filtrate radioactivity. We tested whether any of the radioactivity passing the $0.2 \mu \mathrm{m}$ filters might be cell fragments or macromolecules by passing the filtrates through Gelman Nanospin $4000 \mathrm{MWCO}$ centrifugal ultrafilter units. Two ml of the $0.2 \mu \mathrm{m}$ PES or PC filtrates were placed in the ultrafilter units and these were spun at $10000 \times g$ for $15 \mathrm{~min}$ at $4^{\circ} \mathrm{C}$. From each of the ultrafiltrates, duplicate 
$0.5 \mathrm{ml}$ sub-samples were taken to determine the concentration of radioactivity $\left(\mathrm{dpm} \mathrm{ml}^{-1}\right)$. The concentrations of ${ }^{14} \mathrm{C}$ activity in the $<4000 \mathrm{MW}$ ultrafiltrates were compared with that in the $<0.2 \mu \mathrm{m}$ Supor-PES or Nuclepore-PC filtrates.

A separate experiment tested whether losses from cells on Nuclepore-PC filters occurred during passage of the water sample through the filters or during the drying/rinsing steps at the end of filtration. Sub-samples $(7 \mathrm{ml})$ of a ${ }^{14} \mathrm{C}$-GBT-amended filtrate culture $(1.2 \mathrm{~h}$ after substrate addition) were placed in the Hoefer filter towers over either $0.2 \mu \mathrm{m}$ Supor-PES or NucleporePC filters (duplicates of each). The vacuum ( $5 \mathrm{~cm} \mathrm{Hg}$ ) was turned on until approximately $5 \mathrm{ml}$ of the sample had filtered through. At this point the vacuum was shut off and the partial filtrate $(\sim 5 \mathrm{ml})$ collected and subsampled for the concentration of radioactivity (dpm $\mathrm{ml}^{-1}$ ). New filtrate receptacles were placed and the remaining $2 \mathrm{ml}$ of sample filtered through, with filters being rinsed with $3 \times 0.5 \mathrm{ml}$ of FSW. The filters were counted and the secondary filtrates $(-3.5 \mathrm{ml})$ were subsampled for the concentration of radioactivity $(\mathrm{dpm}$ $\mathrm{ml}^{-1}$ ). Volumes of partial and secondary filtrates were recorded to the nearest $0.1 \mathrm{ml}$ and total dpm in the respective filtrates were calculated from the concentration of radioactivity times the volume of the filtrate. Recovery of radioactivity in each of the 3 fractions (filter + partial filtrate + secondary filtrate and rinse) was $>95 \%$ of the added amount. The range of duplicate determinations of each fraction was less than $10 \%$ of the mean of each

Cold osmotic shock treatment: A cold osmotic shock procedure was used to test whether losses which occurred with Nuclepore filtration might be due to selective loss of periplasmic or outer membrane components of cells. Treatment of cells already filtered onto $0.2 \mu \mathrm{m}$ Supor filters with a cold osmotic shock procedure was compared with filtration of replicate samples of cells onto $0.2 \mu \mathrm{m}$ Nuclepore-PC filters or SuporPES filters without the osmotic shock. The shock procedure, originally adapted from Neu \& Heppel (1965), but optimized for a marine bacterial culture by Martinez \& Azam (1993), is reported to specifically cause release of periplasmic and outer membrane components of bacterial cells, leaving the rell membrane intact. The procedure of Martinez \& Azam (1993) was modified for use with the dilute bacterial suspensions $\left(-2 \times 10^{6}\right.$ cells $\left.\mathrm{ml}^{-1}\right)$ used here. Replicate sub-samples of a filtrate culture which had been amended with ${ }^{14} \mathrm{C}$-GBT or ${ }^{14} \mathrm{C}$-glucose, and incubated for 1 to $2 \mathrm{~h}$, were filtered (10 $\mathrm{cm} \mathrm{Hg}$ vacuum) onto a series of PES and PC filters. After filtering to dryness and rinsing with isotonic FSW, 3 PES and 3 PC filters were taken and immediately placed in Ecolume for counting. With the vacuum turned off, a second set of
PES (in triplicate) was covered with $5 \mathrm{ml}$ of an upshock solution, consisting of $20 \%$ sucrose (w/v) solution prepared in 24 ppt $0.2 \mu \mathrm{m}$-filtered seawater (same water as used for the filtrate culture) and containing $10 \mathrm{mM}$ $\mathrm{Na}_{2}$-ethylenediamine tetra-acetic acid (EDTA). The upshock fluid was allowed to stand on the filters for 15 min, after which time the fluid was filtered through and the filters rinsed with $2 \times 1 \mathrm{mi}$ of upshock fluid. After shutting off the vacuum, the stainless steel filter towers of the Hoefer unit were replaced with new towers which had been sitting on ice (cold towers were dried to remove freshwater before placing on filters). Five $\mathrm{ml}$ of ice cold downshock fluid consisting of $0.2 \mu \mathrm{m}$ filtered seawater ( $24 \mathrm{ppt}$ ) was added to each tower and allowed to sit for $10 \mathrm{~min}$. The downshock fluid was filtered through, and the filters rinsed with $2 \times 1 \mathrm{ml}$ of ice cold downshock fluid before they were removed for counting in Ecolume. Tests showed that ${ }^{14} \mathrm{C}$-actvity lost trom the PES filters during osmotic shock procedures was recovered in the filtrates, with $26 \%$ of the loss occurring in the upshock phase and $74 \%$ of the loss occurring in the downshock phase.

Effects of formalin on ${ }^{14} \mathrm{C}$ retention by cells and different filters: A $36 \mathrm{~h}$ old filtrate culture $(200 \mathrm{ml})$ was treated with approximately $11 \mathrm{nM}{ }^{14} \mathrm{C}-\mathrm{GBT}$. After $1.5 \mathrm{~h}$ the culture was split into two $100 \mathrm{ml}$ aliquots and one of these was treated with $2 \mathrm{ml}$ of borate buffered formalin ( $2 \%$ formalin). The other remained untreated. For the next $1.5 \mathrm{~h}$, sub-samples (in duplicate) were alternately removed from the live and formalin-killed cultures and filtered onto both PES and PC filters.

Isotopes and other chemicals: Methy $]-\left[{ }^{14} \mathrm{C}\right]$ glycine betaine (57 $\mathrm{mCi} \mathrm{mmol}^{-1}$ ) was synthesized from ${ }^{14} \mathrm{C}$ choline (ICN Biomedicals) following the procedures outlined by King (1987). ${ }^{35} \mathrm{~S}-\mathrm{DMSP}$ (37 $\mathrm{mCi} \mathrm{mmol}^{-1}$ ) was synthesized by feeding ${ }^{35} \mathrm{~S} \mathrm{~L}$-methionine to a culture of the phytoplankter Platymonas (= Tetraselmis) subcordiformis. Details on this synthesis and on the purification of ${ }^{35} \mathrm{~S}$-DMSP are given in Kiene et al. (1998). Radiochemical purity of these isotopes was $>99 \%$ based on HPLC and thin layer chromatography. $\mathrm{U}-{ }^{14} \mathrm{C}$-Glucose $\left(354 \mathrm{mCi} \mathrm{mmol}^{-1}\right)$ and ${ }^{14} \mathrm{C}$-Leucine $(320$ $\mathrm{mCi} \mathrm{mmol}^{-1}$ ) were obtained from ICN Biomedicals.

Formalin (37\% formaldehyde) was obtained from Fisher Scientific. All other organic chemicals were obtained from either Sigma or Aldrich and were ACS reagent grade, or better.

Results. Preliminary tests involving uptake of ${ }^{14} \mathrm{C}$ GBT by microbial communities in seawater, showed that $0.2 \mu \mathrm{m}$ Supor-PES filters gave 2- to 4 -fold higher retention of radioactivity than Nuclepore-PC or Anopore-AO filters of comparable pore size. Tests with $0.2 \mu \mathrm{m}$ filtered seawater showed that the higher dpm. retained on Supor-PES filters was not the result of abiological absorption of label by these filters. Also, the 
lower counts obtained with PC filters were not due to an effect of these filters on liquid scintillation counting of ${ }^{14} \mathrm{C}$ or ${ }^{35} \mathrm{~S}$. The retentive characteristics of PES filters in relation to other membrane filters, and the reasons for losses on PC-type filters were explored in greater detail.

Comparisons of filter type, substrate and incubation time: We conducted an experiment which compared 5 different filter types (PES, MCE, PC, PE and Nylon) in microbial isotope uptake assays, using 3 different substrates $\left({ }^{14} \mathrm{C}\right.$-glycine betaine, ${ }^{14} \mathrm{C}$-leucine, and ${ }^{14} \mathrm{C}$-glucose) and 3 different incubation times (10 min, $2 \mathrm{~h}$ and $24 \mathrm{~h})$. Similar patterns with respect to filter and time were observed with each substrate (Fig. 1A, B, C), but the magnitude of responses differed among the substrates. For all 3 substrates, and at all times, the highest retention of radioactivity was observed with either PES, MCE or Nylon filters. These 3 filter types seemed to perform similarly, but in some cases MCE filters retained up to $22 \%$ more radioactivity than the reference Supor PES filters, and these differences were significant $(\mathrm{p}<0.05$; Tukey, pairwise multiple comparisons) with GBT and glucose at $10 \mathrm{~min}$ and $2 \mathrm{~h}$ sampling times. We reiterate that our choice of SuporPES as the reference filter type was arbitrary, and serves only as a basis for comparison. After $24 \mathrm{~h}$, incubation samples filtered onto PES, MCE or Nylon filters gave results within $10 \%$ of one another and the differences were statistically insignificant (Fig. 1A, B, C).

Retention of radioactivity by $P C$ and $P E$ filters was significantly lower than with the other filter types, especially at the $10 \mathrm{~min}$ and $2 \mathrm{~h}$ incubation times (Fig. 1A,B,C). For all 3 substrates, however, the amount of radioactivity collected on $\mathrm{PC}$ and $\mathrm{PE}$ filters (relative to that on Supor-PES) increased with time ( $\mathrm{p}<$ $0.05 ; 2$-way ANOVA). In almost every case, the results with $\mathrm{PC}$ and $\mathrm{PE}$ filters were very similar to those for PES filters that were treated with $5 \%$ TCA, suggesting that PC and PE filters retained most of the macromolecular fraction of the cells but lost the dissolved fraction. The most severe losses (>80\%) on PC and PE filters were observed at $10 \mathrm{~min}$ and $2 \mathrm{~h}$ incubation times when GBT was the substrate (Fig. 1A). When leucine was the substrate (Fig. 1B) the loss was $70 \%$ at $10 \mathrm{~min}$ but only $25 \%$ at $2 \mathrm{~h}$. Similarly, the losses when glucose was the substrate (Fig. 1C) were 46 and $22 \%$ at $10 \mathrm{~min}$ and $2 \mathrm{~h}$ respectively. After $24 \mathrm{~h}$ incubation, filtration of ${ }^{14} \mathrm{C}$-leucine- and ${ }^{14} \mathrm{C}$-glucose-treated samples onto $\mathrm{PC}$ and $\mathrm{PE}$ filters yielded radioactivity lower than, but within $20 \%$ of that found on PES, MCE and Nylon filters. This contrasted somewhat with the ${ }^{14} \mathrm{C}$-GBTtreated samples, which showed large $(-45 \%)$ losses with the PC and PE filters even after $24 \mathrm{~h}$ incubation.

In a separate experiment with more limited filter comparisons, a time-dependent pattern of relative re-

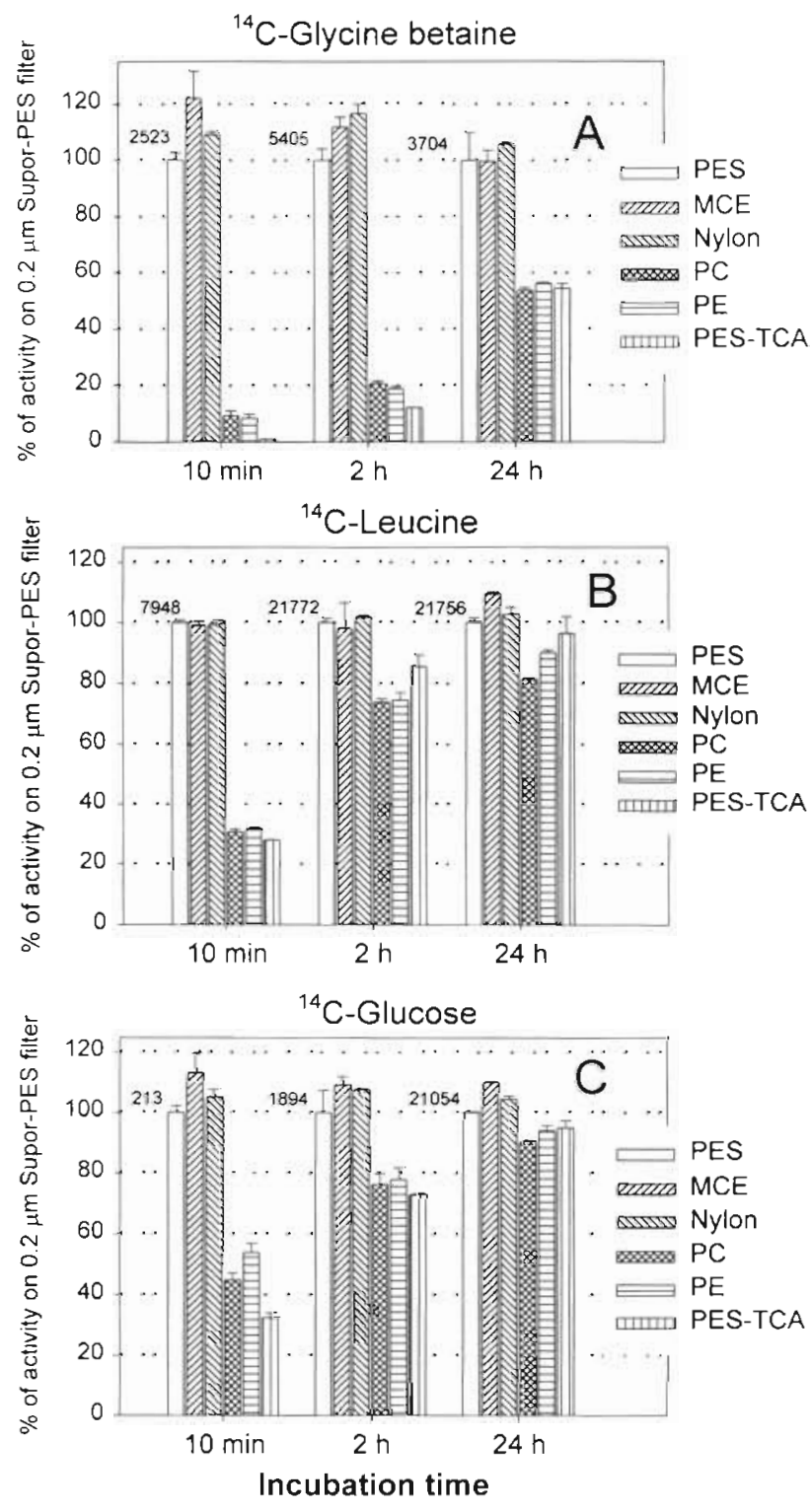

Fig. 1. The relative retention of radiolabeled bacterial cell materials by 5 different $0.2 \mu \mathrm{m}$ pore-size filter types commonly used in microbial uptake studies. The filter types were: PES, polyethersulfone; MCE, Mixed cellulose esters; Nylon, $\mathrm{PC}$, polycarbonate and $\mathrm{PE}$, polyester. Shown are the results at 3 time points for water samples incubated with either (A) $11 \mathrm{nM}{ }^{14} \mathrm{C}$-glycine betaine, (B) $10 \mathrm{nM}{ }^{14} \mathrm{C}$-leucine or (C) $16 \mathrm{nM}^{14} \mathrm{C}$-giucose. Also shown for each time point and substrate are results for PES filters which were treated with $5 \%$ trichloroacetic acid for 5 min after filtration of cells. Other filters were rinsed only with isotonic filtered seawater. Data for each filter type and treatment are expressed as the percent of ${ }^{14} \mathrm{C}$ activity measured on seawater rinsed PFS filters. Mean values of the dpm collected on PES filters are shown next to the white bars. Error bars indicate 1 standard deviation of 3 replicates. All samples were filtered with identical vacuum ( $5 \mathrm{~cm} \mathrm{Hg}$ ) using a multiple-place Hoefer filtration manifold. The filtrate culture used for this experiment was generated from a seawater sample (salinity $=28 \mathrm{ppt}$ ) collected from the west end beach on Dauphin Island, Alabama. The incubation was carried out in the dark at $25^{\circ} \mathrm{C}$ 


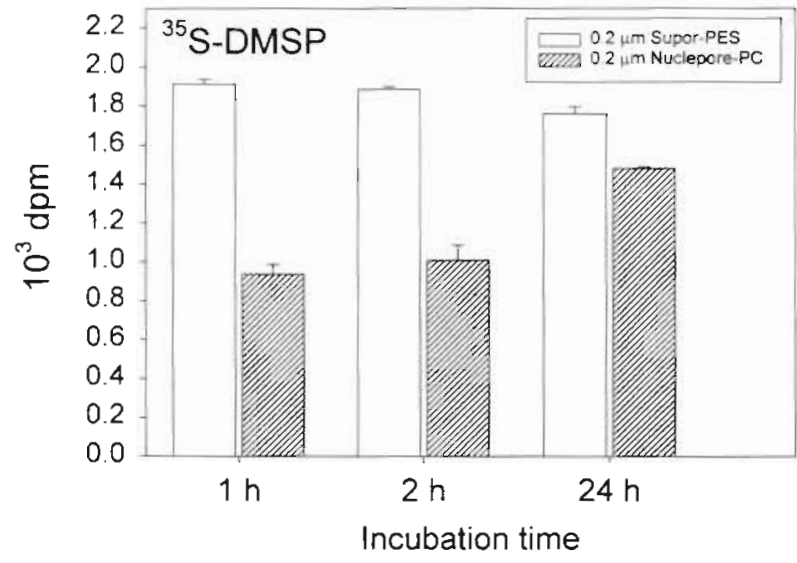

Fig. 2. The relative retention of ${ }^{35} \mathrm{~S}$-laheled cell materials by either $0.2 \mu \mathrm{m}$ Supor-PES or $0.2 \mu \mathrm{m}$ Nuclepore-PC filters. Shown are the results at 3 time points for a filtrate culture (GF/F filtered seawater) incubated with $5 \mathrm{nM}$ 35-DMSP. Error bars indicate 1 standard deviation of 3 replicates. Vacuum was $10 \mathrm{~cm} \mathrm{Hg}$. The water sample (salinity = $18 \mathrm{ppt}$ ) was collected from the west end beach on Dauphin Island. Incubation was in the dark at the in situ temperature of $27^{\circ} \mathrm{C}$

tention between $0.2 \mu \mathrm{m}$ Supor-PES and Nuclepore-PC filters was also observed when $10 \mathrm{nM}{ }^{35} \mathrm{~S}-\mathrm{DMSP}$ was added as the labeled substrate to a $24 \mathrm{~h}$ old filtrate culture (Fig. 2). The PC filters yielded only 49,53 and $84 \%$ of the ${ }^{35} \mathrm{~S}$ activity on PES filters at 1,2 and 24 h of incubation respectively.

Cellular partitioning of isotopes: A time course of uptake and retention of ${ }^{14} \mathrm{C}$-GBT and ${ }^{35} \mathrm{~S}$-DMSP (using $0.2 \mu \mathrm{m}$ Supor filters to capture cells) showed clearly that during the first few hours of incubation, when filtration losses on PC and PE filters were typically greatest (see Figs. $1 \& 2$ ), the majority (>70\%) of the radioactivity retained on filters was found as the untransformed substrate (Fig. 3). With longer incubation times, cells apparently assimilated the acquired substrate and produced labeled cell materials which were non-extractable in MCW (Fig. 3). After $25 \mathrm{~h}$ incubation, when losses using PC and PE filters were typically less than at early time points, the untransformed substrate represented a much lower percentage (31 and $11 \%$ for ${ }^{14} \mathrm{C}$-GBT and ${ }^{35} \mathrm{~S}$-DMSP respectively) of the total radioactivity capturen on the filters. The nonextractable materials represented $\sim 60 \%$ (GBT) and $\sim 70 \%$ (DMSP) of the total radioactivity on filters after $25 \mathrm{~h}$ incubation.

Filter and filtrate label recovery: Using a ${ }^{14} \mathrm{C}$-GBTtreated seawater filtrate culture, we found that radioactivity lost from Nuclepore-PC filters was recovered as excess activity in the filtrate (Table 2), with total recovery (filter + filtrate) being $\geq 95 \%$ for both PES and PC filters. Essentially $100 \%$ of the radioactivity in the $0.2 \mu \mathrm{m}$ filtrates passed through a 4000
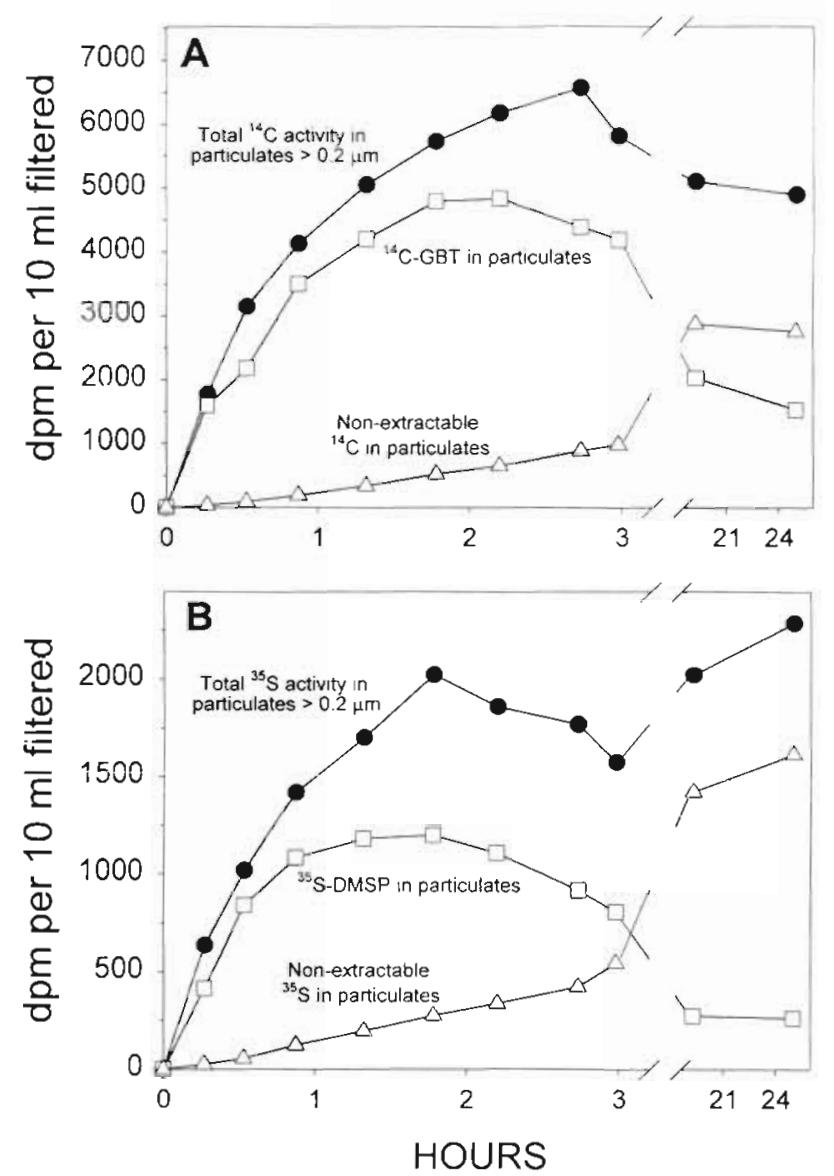

Fig. 3. Time courses of $(\square)$ total particulate radioactivity, $(\square)$ untransformed substrate in particulates, and $(\Delta)$ nonextractable radioactive materials in particulates in a seawater filtrate culture treated with either $(\mathrm{A}){ }^{14} \mathrm{C}$-glycine betaine or (B) ${ }^{35} \mathrm{~S}$-DMSP. Sub-samples $(10 \mathrm{ml})$ of the filtrate cultures were filtered onto $0.2 \mu \mathrm{m}$ Supor-PES filters. Data represent single samples taken at each time. The untransformed substrate and the non-extractable materials represent sub-sets of the total radioactivity captured on filters. The added concentration of ${ }^{14} \mathrm{C}-\mathrm{GBT}$ was $11 \mathrm{nM}$, while that of ${ }^{35} \mathrm{~S}$-DMSP was $9.5 \mathrm{nM}$. Water was collected from Mobile Bay and had a salinity of $17 \mathrm{ppt}$. Incubation was at $27^{\circ} \mathrm{C}$

MWCO ultra-filter indicating that little of the labeled material, including the excess caused by PC filtration, was cell debris or macromolecules.

A subsequent experiment with ${ }^{14} \mathrm{C}$-GBT as the substrate tested whether losses on PC filters occurred during the filtration or at the end of filtration in the rinse steps. Partial filtrates $(5 \mathrm{ml}$ out of $7 \mathrm{ml}$ total) contained similar amounts of radioactivity for either PES or PC filters (Fig. 4). However, the final filtrate + rinses $(3.5 \mathrm{ml})$ of the PC filters contained nearly 3 times the radioactivity of the final filtrate + rinses of the PES filters. As observed previously, the amount of dpm on the PC filters was much lower than for the PES filters, but the total recovery (filter + all filtrates) was similar for both fillter types (Fig. 4). 
Table 2. Recovery of ${ }^{14} \mathrm{C}$ after filtration of a ${ }^{14} \mathrm{C}$-glycinebetaine-treated filtrate culture through $0.2 \mu \mathrm{m}$ Supor-PES and Nuclepore-PC filters. SD: standard deviation

\begin{tabular}{|lcccc|}
\hline Pool & $\begin{array}{c}\text { Supor-PES filters } \\
\text { Meari" }\end{array}$ & SD & $\begin{array}{c}\text { Nuclepore-PC filters } \\
\text { Mean" }\end{array}$ & SD \\
\hline Filter dpm & 6673 & 84 & 1745 & 65 \\
Filtrate dpm & 8319 & 624 & 12894 & 45 \\
Filter + filtrate dpm & 15014 & 575 & 14661 & 20 \\
\% of added isotope recovered & 97.7 & 4 & 95 & 0 \\
Ultrafiltrate of filtrate dpm & 8622 & 245 & 12985 & 286 \\
Ultrafiltrate as \% of filtrate dpm & 104 & 6 & 101 & 2 \\
& & & \\
alues represent the mean of triplicate filters of each type & \\
'Viltrate and ultrafiltrate dpm values represent the amount in the total \\
filtrate estimated from the concentration of radioactivity in sub-samples of \\
each fraction and the volume of each fraction \\
\hline
\end{tabular}

Effects of cold osmotic shock: A cold osmotic shock treatment, which involved first an upshock and then a downshock, caused cells filtered onto Supor-PES filters to lose a substantial amount of radioactivity as compared with those not receiving the osmotic shock (Fig. 6). The amount of activity on PES filters after cells were osmotically shocked was very similar to the amount retained on PC filters when cells were not shocked, and this was true when either ${ }^{14} \mathrm{C}$-GBT (Fig. 6A) or ${ }^{14} \mathrm{C}$-glucose (Fig. 6B) were the substrates taken up. As observed previously, the losses upon filtration onto PC filters were much less for ${ }^{14} \mathrm{C}$-glucose-treated samples than for ${ }^{14} \mathrm{C}$-GBT-treated samples (Fig. 6). A subsequent experiment (data not shown) reveled that subjecting bacteria on PC filters to cold osmotic shock caused loss of an additional $50 \%$ of the radioactivity compared with unshocked cells on PC filters. In a separate test, it was found that even a modest osmotic downshock (no upshock involved) could result in significant losses of cellular radioactivity. When a high salinity (37 ppt), ${ }^{14} \mathrm{C}$-GBT-treated filtrate culture was rinsed with either 24 ppt FSW or 37 ppt FSW, the amount of radioactivity on the 24 ppt-rinsed filters was $40 \%$ lower than that on the 37 ppt-rinsed filters.

Effects of formalin: The effects of formalin on the patterns of radioisotope retention by $0.2 \mu \mathrm{m}$ Supor-PES

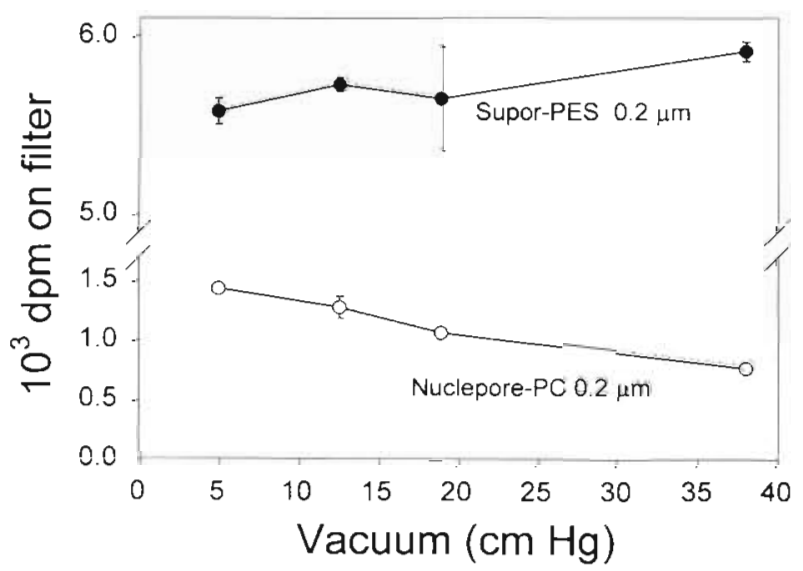

Fig. 5. Effects of filtration vacuum on retention of ${ }^{14} \mathrm{C}$-activity by either $0.2 \mu \mathrm{m}$ Supor-PES filters or $0.2 \mu \mathrm{m}$ Nuclepore-PC filters. Five $\mathrm{ml}$ sub-samples (in triplicate) of a ${ }^{14} \mathrm{C}$-glycine betaine-treated filtrate culture were passed through each filter type at each of the vacuums shown. Error bars represent 1 standard deviation of 3 replicates and are smaller than the symbol in some cases. Note the break in scale. The dpm on Supor filters increased $6 \%$ from the lowest to highest vacuum, whereas the dpm on Nuclepore filters decreased by $46 \%$ from the lowest to highest vacuum 

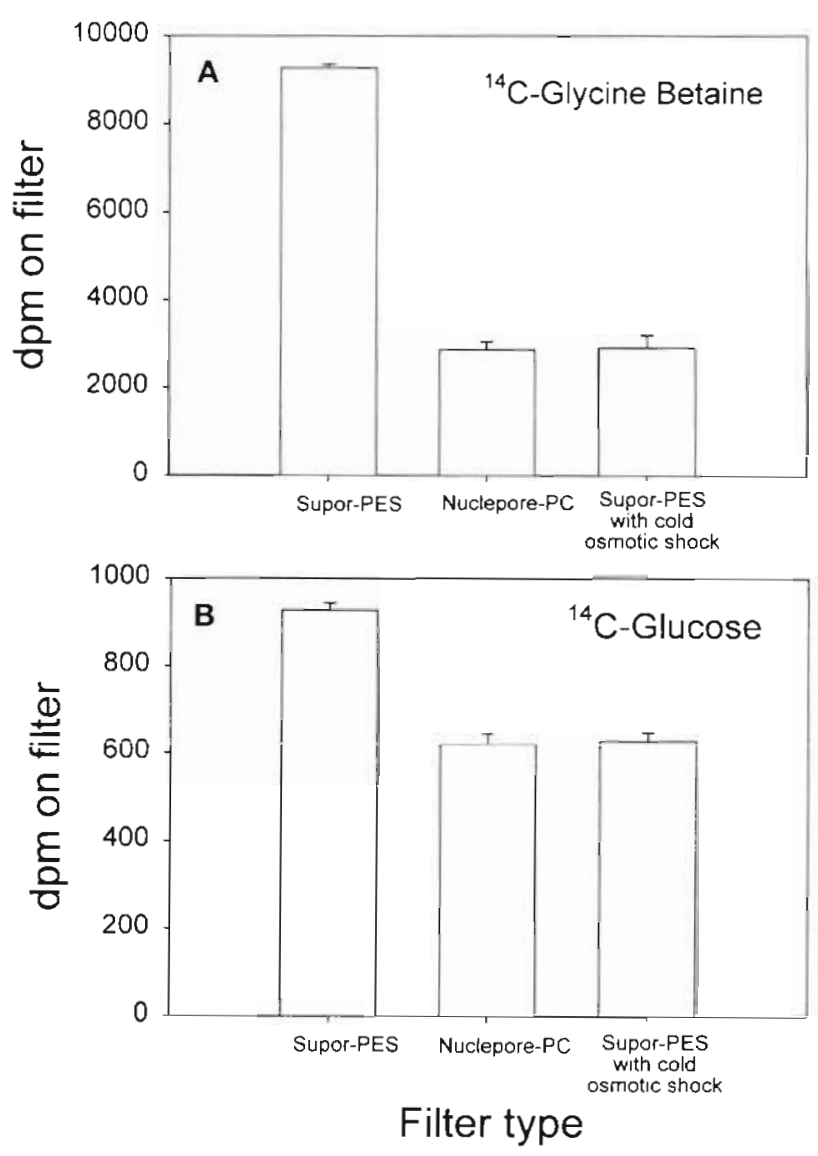

Fig. 6. The relative retention of ${ }^{14} \mathrm{C}$-labeled cell materials by either $0.2 \mu \mathrm{m}$ Supor-PES or $0.2 \mu \mathrm{m}$ Nuclepore-PC filters taken with standard procedures (rinsing with isotonic filtered seawater) and that of $0.2 \mu \mathrm{m}$ Supor-PES filters subjected to a cold osmotic shock procedure, as described in the text. Shown are data from filtrate cultures treated with $(\mathrm{A}){ }^{14} \mathrm{C}$-glycine betaine and (B) ${ }^{14} \mathrm{C}$-glucose, and sampled at 1 to $2 \mathrm{~h}$ after substrate addition. Error bars indicate one standard deviation of 3 replicates. Vacuum was $10 \mathrm{~cm} \mathrm{Hg}$. The water sample was collected from the east end pier on Dauphin Island and had a salinity of $24 \mathrm{ppt}$. Incubation was in the dark at the in situ temperature of $23^{\circ} \mathrm{C}$

and Nuclepore-PC filters was tested by adding formalin $(2 \%$ final concentration) to a filtrate culture which had already been allowed to take up ${ }^{14} \mathrm{C}$-GBT for $1.5 \mathrm{~h}$ (Fig 7). Direct measurement confirmed that, at this time iniu line incubation, $82 \%$ of the label in cells wâs untransformed ${ }^{14} \mathrm{C}$-GBT, while only $7 \%$ was nonextractable materials (see also results above), Parallel live samples (no formalin) filtered onto PES filters showed relatively constant amount of radioactivity at different time points over a $1.5 \mathrm{~h}$ period (Fig. 7 ). In contrast, filterable radioactivity (onto PES filters) in formalin-treated samples decreased exponentially from 3400 dpm to $770 \mathrm{dpm} 5 \mathrm{ml}^{-1}$ in about $1.5 \mathrm{~h}$. Sub-samples from the same formalin-treated bottle filtered onto PC filters showed similar amounts of radioactivity to live

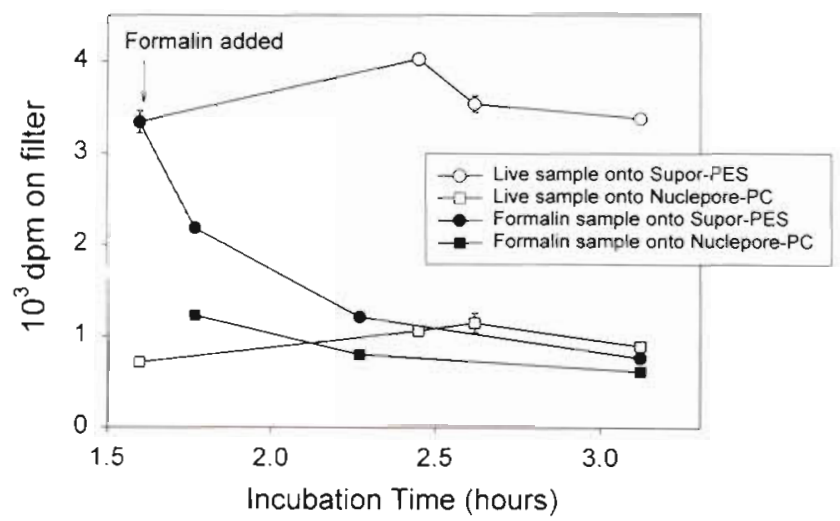

Fig. 7 . The effects of adding $2 \%$ formalin (closed symbols) on the amount of radioactivity captured by either $0.2 \mu \mathrm{m}$ SuporPES $(\bullet, 0)$ or Nuclepore-PC $(\square, 0)$ filters. Data from live samples (open symbols) are also shown. In this experiment, a filtrate culture was amended with $10 \mathrm{nM}{ }^{14} \mathrm{C}$-glycine betaine 1.5 in prior to initiation of filter tests, so cells had accumulated ${ }^{14} \mathrm{C}$-activity. Data points represent the mean of duplicate samples at each time, with bars indicating the range. Bars are smaller than the symbols in some cases

samples filtered onto PC filters, and both of these gave very much lower radioactivity than live samples filtered onto PES filters. Formalin-PES, formalin-PC and live-PC filter samples converged after $1.5 \mathrm{~h}$ at about $20 \%$ of the dpm obtained with live samples filtered onto PES filters (Fig. 7).

In other tests carried out with ${ }^{14} \mathrm{C}$-GBT, there were no substantial differences between the performance of Nuclepore brand versus Poretics brand $0.2 \mu \mathrm{m}$ PC filters; both gave poor retention of radioactivity compared with Supor-PES filters. It also made no difference whether a backing filter (a $0.2 \mu \mathrm{m}$ Supor-PES) was used under the PC filters on the Hoefer filtration manifold. In addition, leaving the PC filter dry on the filter tower, after the sample had filtered through for $\sim 1$ to $2 \mathrm{~s}$ (the minimum time possible and the standard time used) gave results which agreed, within 10\%, with filters left dry and the vacuum on, for up to $60 \mathrm{~s}$ (data not shown).

Discussion. Loss of organic matter during filtration of microorganisms is a serious concern because it results in underestimation of particulatc matcrial and overestimation of dissolved material. Conditions of filtration and the type of filter used are known to affect the release of dissolved organic matter (DOM) from natural aquatic microbial communities (Fuhrman \& Bell 1985, Nagata \& Kirchman 1990). DOM release is usually attributed to rupture of delicate phytoplankton and microzooplankton, but few studies have considered that bacteria might lose cell materials as well. The results of our study showed that major losses of labeled cell materials occurred when live assemblages of bac- 
terioplankton were filtered onto $0.2 \mu \mathrm{m}$ Nuclepore-PC or Poretics-PE filters, and that the magnitude of these losses depended on the incubation time and the type of substrate taken up (Figs. 1 \& 2). The significant losses observed with these PC and PE filters (observed also with $0.2 \mu \mathrm{m}$ Poretics-PC and Anopore-AO filters) probably resulted from the selective loss of dissolved cell components during the final stages of filtration, including the rinse steps (Fig, 4). That PC and PE filters produced results very similar to one another (Fig. 1) was not surprising because the specifications and characteristics of track-etched PC and PE membranes are similar in almost every respect (Poretics Products, Catalog 1997-98). Cells caught on the very flat, hydrophobic surfaces of PC and PE membranes may become desiccated and leaky when the filters become dry at the end of filtration. Leaked bacterial cell materials are probably lost from the filters during the rinse steps which are necessary to wash away non-cell associated radioactive substrates. Our findings are similar to those of Goldman \& Dennett (1985), who concluded that certain delicate phytoplankton released DOM if glass fiber filters were allowed to dry during filtration.

In our study, which focused on bacterioplankton, filter membranes that captured cells in, or on, a spongelike matrix (e.g. PES, MCE and Nylon types) generally had the highest retention of radiolabeled cell materials, and therefore did not appear to cause massive cell leakage. It should be noted, however, that PES filters sometimes retained less labeled cell material than MCE or Nylon filters (Fig 1A, C), therefore we cannot exclude the possibility that some cell leakage occurred with PES filters. We note that, with respect to uptake assays, no objective standard filter material exists, so we can only compare the performance of filter types with one another. Overall, retention of labeled cell materials by PES, MCE and Nylon filters differed by less than $22 \%$ in all cases and by less than $10 \%$ in most cases, therefore, depending on the needs of the study, each of these filter types may be suitable for uptake determinations. Matrix filters such as these probably hold sufficient water to prevent desiccation of trapped bacterial cells, thereby minimizing loss of cell materials during the filtration/rinsing procedures. Cell protection on PES filters was apparently quite effective because variations in filtration vacuum from 5 to $39 \mathrm{~cm}$ $\mathrm{Hg}$ had little effect on retention of labeled cell material by these filters (Fig. 5). This was in contrast to PC filters which retained less cell material at higher filtration vacuum (Fig. 5).

Mixed cellulose ester (MCE, cellulose acetate and cellulose nitrate) filters (e.g. Metricel and HA Millipore) are perhaps the most commonly used filters in uptake studies with natural assemblages of microorganisms (e.g. Wright \& Hobbie 1966, Coffin 1989, Rich et al. 1996). However, $0.2 \mu \mathrm{m}$ Nuclepore filters have also been used extensively (Azam \& Hodson 1981, Palumbo et al. 1983, Ferguson \& Sunda 1984, Griffith et al. 1990). Future studies employing filters for capture of live cells should consider potential differences in retention efficiency and the possible artifactual release of DOM from the bacterioplankton under conditions which subject cells to desiccation, osmotic shock or poisons (see also below).

An important conclusion which can be drawn from the present work is that harsh filtrations or other manipulations (osmotic shock and poisoning) caused substantial loss of dissolved components of bacterioplankton cells while cellular macromolecules remained in filterable form. The time dependence of filtration losses on $\mathrm{PC}$ and $\mathrm{PE}$ filters (greater relative losses at earlier time points) observed with either ${ }^{14} \mathrm{C}$ GBT or ${ }^{35} \mathrm{~S}$-DMSP appeared to be related to the fraction of cellular radiolabel that was still in the untransformed state, and therefore dissolved in the cell. Losses with PC and PE filters were greatest (50 to $90 \%$ loss relative to PES filters) during the first few hours of incubations (Figs. $1 \& 2$ ), when, in the case of ${ }^{14} \mathrm{C}$-GBT and ${ }^{35} \mathrm{~S}$-DMSP, 70 to $90 \%$ of the radiolabel on the filters was present as the untransformed substrate (Fig. 3). During later phases of incubations (i.e. $-24 \mathrm{~h}$ ), when untransformed substrate comprised a much smaller fraction (22 to $30 \%$ ) of the label on the filters (Fig. 3) and when most of the radiolabeled material on filters was in a methanol-insoluble (macromolecule) pool, losses on PC filters were less severe ( 20\%). The fact that most of the material lost from cells upon filtration through PC filters was dissolved and low molecular weight (i.e. $<4000 \mathrm{MW}$; Table 1), supports the hypothesis that the lost material was mostly untransformed parent compound $\left({ }^{14} \mathrm{C}-\mathrm{GBT}\right.$ in this case). If we assume that the newly acquired radiolabeled substrate acts as a proxy for other soluble cell components, then we can conclude that a major fraction of the dissolved, low molecular weight compounds associated with bacterial cells are lost upon filtration onto PC-type membranes and by procedures which subject cells to osmotic shock or poisoning. The osmotic solutes GBT and DMSP were particularly useful in revealing the loss of this dissolved pool from the cells because these compounds tend to accumulate intracellularly, perhaps to a greater degree than other substrates. We did not measure intracellular pooling of leucine or glucose, but these substrates appeared to be assimilated into TCA insoluble cellular macromolecules more rapidly than GBT or DMSP (Figs. 1 \& 2). Simon \& Azam (1989) have measured intracellular pools of leucine in marine bacteria, and observed that this pool turns over rapidly during bacterial growth as the leucine is assimilated into cellular proteins. 
The exact location (periplasmic or cytosolic) of the easily-lost, dissolved cellular material is presently unknown. The results with cold osmotic shock treatment of cells which had taken up ${ }^{14} \mathrm{C}$-GBT or ${ }^{14} \mathrm{C}$-glucose (Fig. 6) suggest that periplasmic and outer membrane (rather than cytosolic) components of bacterial cells might be selectively lost upon filtration onto PC filters. However, this conclusion may not be valid, because of the way we carried out these tests. A key difference in our procedure compared with that of Martinez \& Azam (1993) was that we filtered cells onto a membrane before subjecting them to the osmotic shocks while they centrifuged the cells into a pellet, which was resuspended in shock fluid, and then recentrifuged. We suspect that the spheroplasts generated by the osmotic shock procedure may have been susceptible to breakage or leakage during vacuum filtration. While we cannot draw firm conclusions about the cellular location of material lost curing osmotic shock, our results do suggest that the dissolved fraction. of cells was lost. Cold osmotic shock of cells on PES filters produced nearly identical results as filtration of the same samples onto $\mathrm{PC}$ filters with no osmotic shock (Fig. 5), and this was true when either ${ }^{14} \mathrm{C}-\mathrm{GBT}$ or ${ }^{14} \mathrm{C}$ glucose were the substrates taken up. In addition, we found that simply rinsing PES filters with hypotonic FSW (24 ppt rinse vs 37 ppt natural salinity) caused substantial $(40 \%)$ loss of radioactivity from PES filters (data not shown). Osmotic shock, therefore appears to be an important factor which can affect retention of cell materials on filters

The results from the formalin addition experiment (Fig. 7) showed that addition of $2 \%$ buffered formalin to terminate uptake incubations can result in serious underestimation of total ${ }^{14} \mathrm{C}$-GBT uptake. This was evident only when PES filters were used and not when PC filters were used, due to the fact that formalin caused release of ${ }^{14} \mathrm{C}$ label to the same extent as filtration onto PC filters (Fig. 7 ). Palumbo et al. (1983) concluded that addition of $0.6 \%$ formalin to terminate incubations did not affect uptake assays of tritiated amino acids. However, that study utilized $0.2 \mu \mathrm{m}$ Nuclepore-PC filters, so all uptake may have been underestimated. The results presented here support earlier studies which found rnat formalin caused losses of labeled (Griffiths ct al. 1974) and unlabeled (Wolfe 1996) substrates taken up by marine bacteria. Formalin does not appear to cause cell disruption because fixed bacterial cells are usually well defined when examined by epifluorescence microscopy on Nuclepore filters (Hobbie et al 1977. Porter \& Feig 1980). Formalin must therefore cause release of soluble compounds from the cells, which could include cytosolic and periplasmic components. The similar losses of radioactivity observed with filtration of live cells onto PC filters and of formalin treated samples onto PES filters suggests that these treatments cause the same pool of material to be lost from cells

In conclusion, matrix-type filters including PES, MCE and Nylon appear to be the most suitable for capture of live cells with minimal release of dissolved cell components. Some differences in performance of these filters flower retention on PES filters in some cases) makes it advisable that researchers compare selected filter-types and evaluate their suitability for the intended work. Most importantly, this study provided evidence that marine bacteria release a large fraction of their dissolved cellular material upon harsh filtration (e.g onto PC-type filters), osmotic shock, or formaldehyde treatment. The phenomenon of DOM release may be a general response of stressed bacterial cells and of some concern to microbial ecologists studying material cycling by bacterioplankton.

Acknowledgements. The authors wish to thank Gordon Wolfe for stimulating discussions on the subject of osmolyte uptake. Joel Walker and Ted Stets assisted in several aspects of the work. Funding for this research was provided by the National Science Foundation, grants OCE-9218511 and OCE-9530378.

\section{LITERATURE CITED}

Azam F, Hodson RE (1981) Multiphasic kinetics for D-glucose uptake by assemblages of natural marine bacteria. Mar Ecol Prog Ser 6:213-222

Coffin RB (1989) Bacterial uptake of dissolved free and combined amino acids in estuarine waters. Limnol Oceanogr 34:531-542

DeLong EF: Yayanos AA (1987) Properties of the glucose transport system in some deep-sea bacteria. Appl Environ Microbiol 53:527-532

Ferguson RL, Sunda WG (1984) Utilization of amino acids by planktonic marine bacteria: importance of clean technique and low substrate additions. Limnol Oceanogr 29:258-274

Fuhrman JA, Bell TM (1985) Biological considerations in the measurement of dissolved free amino acids in seawater and implications for chemical and microbiological studies. Mar Ecol Prog Ser 25:13-21

Goldman JC, Dennet MR (1985) Susceptibility of some marine phytoplankton species to cell breakage during filtration and post-filtration rinsing. J Exp Mar Biol Ecol 86:47-58

Griffith PC, Douglas DJ, Wainright SC (1990) Metabolic activity of size-fractionated microbial plankton in estuarine, nearshore, and continental shelf waters of Georgia. Mar Ecol Prog Ser 59:263-270

Grifilins RP, I lanis Ir, Morita RY (1974) The effects of varions water-sample treatments on the apparent uptake of glutamic acid by natural microbial populations. Can J Microbiol 20:1261-1266

Hobbie JE, Daley RJ, Jasper S (1977) Use of Nuclepore filters for counting bacteria by fluorescence microscopy. Appl Environ Microbiol 33:1225-1228

Hodison R, Azam F, Carlucci A, Fuhrman J, Karl D, HolmHansen O (1981) Microbial uptake of dissolved organic matter in McMurdo Sound A.ntarctica. Mar Biol 61:89-94

Kiene RP, Hoffmann Williams LP (1998) Glycine betaine uptake, retention and degradation by microorganisms in seawater. Limnol Oceanogr 43:1592-1603 
Kiene RP, Hoffmann Williams LP, Walker JE (1998) Seawater microorganisms have a high affinity glycine betaine uptake system which also recognizes dimethylsulfoniopropionate. Aquat Microb Ecol 15:39-51

King GM (1987) An enzymatic synthesis of specifically radiolabeled derivatives of the common osmolyte, glycine betaine. J Exp Mar Biol Ecol 107:145-154

Kirchman DL, K'nees E, Hodson R (1985) Leucine incorporation and its potential as a measure of protein synthesis by bacteria in natural aquatic systems. Appl Environ Microbiol 49:599-607

Logan BE, Kirchman DL (1991) Uptake of dissolved organics by marine bacteria as a function of fluid motion. Mar Biol 111:175-181

Martinez J, Azam F (1993) Periplasmic aminopeptidase and alkaline phosphatase activities in a marine bacterium: implications for substrate processing in the sea. Mar Ecol Prog Ser 92:89-97

Middelboe M, Borch NH, Kirchman DL (1995) Bacterial utilization of dissolved free amino acids, dissolved combined amino acids and ammonium in the Delaware Bay: effects of carbon and nitrogen limitation. Mar Ecol Prog Ser 128:109-120

Nagata T, Kirchman DL (1990) Filtration-induced release of dissolved free amino acids: application to cultures of marine protozoa. Mar Ecol Prog Ser 68:1-5

Editorial responsibility: Jed Fuhrman,

Los Angeles, California, USA
Neu H. Heppel L (1965) The release of enzymes from Eschericia coll by osmotic shock and during the formation of spheroplasts. J Biol Chem 240:3685--3692

Palumbo A, Ferguson R, Rublee P (1983) Efficient utilization of dissolved free amino acids by suspended marine bacteria. J Exp Mar Biol Ecol 69:257-266

Potter KG, Feig YS (1980) The use of DAPI for identufying and counting aquatic microfiora. Limnol Oceanogr 25 $943-948$

Rich JH, Ducklow HW, Kirchman DL (1996) Concentrations and uptake of neutral monosaccharides along $140^{\circ} \mathrm{W}$ in the equatorial Pacific: contribution of glucose to heterotrophic bacterial activity and DOM flux. Limnol Oceanogr 41:595-604

Simon M, Azam F (1989) Protein content and protein synthesis rates of planktonic marine bacteria. Mar Ecol Prog Ser 51:201-213

Wolfe GV (1996) Accumulation of dissolved DMSP by marine bacteria and its degradation via bactivory. In: Kiene RP, Visscher PT, Keller MD, Kirst GO (eds) Biological and environmental chemistry of DMSP and related sulfonium compounds. Plenum, New York, p 277-291

Wright RT, Hobbie JE (1966) Use of glucose and acetate by bacteria and algae in aquatic ecosystems. Ecology 47 $447-464$

Submitted: October 12, 1998; Accepted: January 27, 1999 Proofs received from author(s): June 9, 1999 